\title{
Novel behavioural assay and partial purification of a female-derived sex pheromone in Carcinus maenas
}

\author{
J. D. Hardege ${ }^{1, *}$, A. Jennings ${ }^{1}$, D. Hayden ${ }^{1}$, C. T. Müller ${ }^{1}$, D. Pascoe ${ }^{1}$, \\ M. G. Bentley ${ }^{2, * *}$, A. S. Clare ${ }^{3, * *}$ \\ ${ }^{1}$ Cardiff School of Biosciences, Cardiff University, Park Place, PO Box 915, Cardiff CF1 3TL, United Kingdom \\ ${ }^{2}$ Gatty Marine Laboratory, University of St Andrews, St Andrews KY16 8LB, United Kingdom \\ ${ }^{3}$ Marine Biological Association of the United Kingdom, The Laboratory, The Hoe, Citadel Hill, Plymouth PL1 2PB, \\ United Kingdom
}

\begin{abstract}
Experiments were conducted to test the hypothesis that females of the shore crab Carcinus maenas release a sex pheromone to induce the pre-copula behaviour leading to the formation of mating pairs. In the novel behavioural assay, a positive response to a female-derived signal involves 'homosexual' behaviour: a pre-copula male moves towards another pre-copula male that has been 'exposed' to the substance(s) under investigation. The assay male grasps the 'pheromone-treated' male (the 'pseudo-female') to test the hardness of the cuticle with its chelipeds, and invariably proceeds to manipulate the pseudo-female beneath its abdomen as in pre-copula ('homosexual pair formation'). Control males show an agonistic behaviour towards each other. Male shore crabs will also attempt to pair with non-crab-like objects, such as stones, if these are conditioned with female pheromone. This demonstrates that male mate selection in Carcinus maenas is based primarily on the detection of female odour compounds. Urine collected from the urinary bladder of pre-copula females, as well as 'culture water' obtained from these females, elicited a positive response, whereas similar samples collected from inter-moult females failed to induce a sexual response in males. Preliminary characterisation of the 'waterborne cue(s)' revealed the sex pheromone(s) to be smaller than 1000 Da molecular weight, sparingly soluble in organic solvents, lyophilisable, and chemically distinct from 20-hydroxyecdysone (crustecdysone) and arthropodin. Crustecdysone showed no biological activity in the assay and was not detectable in the bioactive HPLC fraction. Although this does not completely rule out a steroidal character for the sex pheromone, LC-MS analyses utilising electrospray and atmospheric pressure chemical ionisation (APCI) did not show a steroid in the bioactive fraction.
\end{abstract}

KEY WORDS: Sex pheromone $\cdot$ Shore crab · Bioassay $\cdot$ Carcinus maenas $\cdot$ 20-hydroxyecdysone

\section{INTRODUCTION}

Although many forms of behaviour have been described as being controlled via chemical communi-

Present addresses:

*Department of Biological Sciences, Hull University, Cottingham Road, Hull HU6 7RX, United Kingdom.

Email: j.d.hardege@hull.ac.uk

${ }^{* *}$ School of Marine Sciences, Ridley Building, University of Newcastle, Newcastle upon Tyne NE1 7RU, United Kingdom cation, e.g. predator-prey interactions, larval settlement and sexual reproduction, only a few signal molecules have been identified in marine organisms (Hardege 1999). Arguably, the most thoroughly investigated chemical communication systems in invertebrates are those involved in reproduction. To date, our knowledge is most advanced in the control of marine invertebrate reproduction in nereidid polychaetes, from which a number of sex pheromones have been identified recently (Zeeck et al. 1988, 1996, 1998, Hardege et al. 1994, 1996, 1998, Ram et al. 1999). 
The existence of a female sex pheromone in crustaceans was first demonstrated in Portunus sanguinolentus (Ryan 1966). Since then, the list of crustacean species for which there is evidence of a sex pheromone has become extensive and still continues to grow (Dunham 1988, Bouchard et al. 1996). It includes the lobster Homarus americanus, where females orientate towards male burrows in response to sex attractants emitted by males and female-produced sex pheromones control mating behaviour (Cowan \& Atema 1990). In the blue crab Callinectes sapidus, Gleeson $(1980,1982,1991)$ and colleagues (Gleeson et al. 1984) described the presence of 3 pheromones in female urine that were attractive to males. Although some progress has been made in the purification of the latter (Gleeson et al. 1984), no sex pheromone has been characterised.

The female sex pheromone is one of only a few crustacean pheromones so far demonstrated. The beststudied are the pheromones involved in barnacle egg hatching and gregarious settlement (e.g. Clare 1995, Clare \& Matsumura 2000). One of these pheromones, the cuticular glycoprotein, arthropodin (synonyms: settlement pheromone, settlement-inducing protein complex) that mediates settlement of cypris larvae, has also been postulated by Dunham (1988) as a candidate for the female crab sex pheromone; however, so far no experimental data are available to confirm this theory. It is clear that, despite a considerable amount of research effort and much interest in the reproductive biology of crab species, little real progress has been made in answering fundamental questions concerning chemical communication and sex pheromones in these species.

In his comprehensive reviews, Dunham $(1978,1988)$ attributed the relatively slow progress to the unreliability of the bioassays employed, the main problem being the inability to discriminate sex pheromones from other chemical signals, such as food and/or visual and tactile cues. Dunham $(1978,1988)$ particularly highlighted the problems associated with the attraction chamber assays used by Kittredge et al. (1971) and others (Eales 1974, Seifert 1982). A key factor in all behavioural assays is the need to employ males that are receptive to female pheromone (see Bamber \& Naylor 1996a) and the ability to differentiate between sexual behaviours (e.g. attraction, courtship display) and other environmental signals, such as food attractants (Dunham 1978). The latter applies to assays of attraction towards a source (chemotactic response) in a Y-shaped olfactometer, such as those frequently used for insects. Behavioural assays based on a distinctive sexual behaviour, i.e. a 'releaser reaction', are a more reliable means of investigating the role of sex pheromones (Dunham 1978, 1988). Visual and tactile cues may also play an important role in orientation towards the sexual partner and formation of pairs. Much effort has been directed towards the development of bioassay techniques, which eliminate these cues by spatial separation and the use of darkened assay chambers (Seifert 1982, Bamber \& Naylor 1996a). Light beams used in actograph designs have proved effective, but as with Y-shape olfactometers, such systems are not capable of discriminating between sexual attraction and other signals, such as food (Dunham 1988).

As in most crustaceans, mating in the shore crab Carcinus maenas is coincident with the female moult (Hartnoll 1969) and copulation occurs shortly after this event. For 2 d prior to female moulting, the sexual partners will typically pair, with the male guarding and defending the female against predators and other competitor males. When the male is first attracted to the female, he typically displays a stereotyped behaviour in which the male rises up on Pereiopods 2 to 4, essentially on 'tip toe', and advances slowly towards the female (Bamber \& Naylor 1996a). This forward searching behaviour can be elicited by the presence of precopula females and also by exposure to their urine, indicating the importance of a female sex pheromone (Christofferson 1978, Bamber \& Naylor 1996b). Urine collected from pre-moult females induced sexual behaviour in male crabs when tested using an actograph (Bamber \& Naylor 1996a). Experimental blockage of the site of urine release, the antennal gland opercula, however, failed to diminish the chemical attractiveness of the females (Bamber \& Naylor 1996c). This indicates at least 1 further site of pheromone release or the presence of more than 1 active compound (Bamber \& Naylor 1996c).

The male antennules bear the receptors for female sex pheromone in Callinectes sapidus (Gleeson 1980), Carcinus maenas (Bamber \& Naylor 1996a) and probably other species. Consequently, electrophysiological recordings from the antennules have been suggested as a pheromone assay by a number of authors (see Gomez \& Atema 1996). Although an electrophysiological bioassay is a valuable tool to test that a chemical signal is detected and that an internal reaction in the receiving animal is evoked, such tests are not a replacement for behavioural assays, as they give no indication of the behavioural effects due to chemical cues.

Dunham (1988) listed a number of criteria required for the development of a behavioural bioassay for the detection of a female produced sex pheromone. These include limitation of the influence of other modes of signalling, such as visual cues, the development of internal negative controls, the use of 'blind' assays in which the observer is not aware of the nature of the substances under investigation and a clear behavioural 
reaction to a cue. The formation of a pair follows the initial stages of male and female activation (standing on 'tip toe') and although attraction represents a distinctive behaviour, it could still include optical as well as tactile cues. Such assays also provide little information on the motivation of the animal's response, i.e. they cannot discriminate between attraction towards food and sex. Two earlier observations on crustacean reproductive behaviour were helpful in overcoming these problems. First, in Gammarus duebenii, Hartnoll \& Smith (1980) found that pair formation occurred only in heterosexual conspecifics and only involved premoult females. Similarly, Gleeson (1980) in his experiments with the blue crab Callinectes sapidus, only scored a male's response towards a female-produced cue as positive if courtship behaviour with other males in the test aquarium was elicited. These assays were run with many males in a test tank and the substances were added by pipette. However, Gleeson (1980) did not systematically develop this into a bioassay and thus, omitted both positive and negative controls as well as blind testing, and in addition, no note was made of the absence of homosexual approaches in males. Using shore crab males, we decided to establish a male 'homosexual' response to the presence of female sex pheromone (initiate pairing) as a behavioural assay. Here, we report on the development of this new, rapid, simple, reliable and unambiguous behavioural bioassay. We have used this assay to aid in the preliminary purification of the female sex pheromone of the shore crab Carcinus maenas, and present here chromatographic and spectroscopic data on this pheromone.

\section{MATERIALS AND METHODS}

Collection and maintenance of crabs. Carcinus maenas were collected during the breeding season (from April to October) at Forder, Tamar Estuary, Cornwall, at periods of low tide from a rocky intertidal. Only male-guarded females (both, pre- and post-copula stage) that were found in 'pairs' were collected. The sexes were separated and female crabs were held individually in a flow-through seawater system. Males were maintained in aquaria and held in groups of 5 to 7 crabs with a seawater flow-through system and were separated $3 \mathrm{~h}$ prior to any behavioural experiment. Feeding was undertaken twice a week using fresh Mytilus edulis or white fish.

Bioassay procedure. Behavioural assays were undertaken in clear plastic aquaria $(30 \times 20 \mathrm{~cm})$ holding $10 \mathrm{l}$ of $0.2 \mu \mathrm{m}$ filtered, UV-sterilised seawater at ambient temperature $\left(18^{\circ} \mathrm{C}\right)$. All assay tanks were placed in brown cardboard boxes to avoid interference by mirror effects. Crabs were placed into the tanks $2 \mathrm{~h}$ prior to the experiments to allow acclimatisation. This adaptation period at reduced light levels resulted in a cessation of activity of the crabs, which invariably stayed in a corner of the tank. The bioassay procedure involves a male, either intermoult or pre-copula, being dipped into pre-copula female-conditioned seawater (16 females in $800 \mathrm{ml}, 0.45 \mu \mathrm{m}$ filtered, UV irradiated) and introduced into a tank containing a pre-copula male. A positive bioassay result requires a specific, stereotyped behavioural response in which the precopula male grasps the 'pheromone-treated male', the so-called 'pseudo-female', and tests the hardness of the cuticle with its chelipeds. This reproductive behaviour contrasts with the response elicited by exposure to food, during which mouthparts are examined, and also with the normal aggressive behaviour by males. While this constitutes a positive response, the pre-copula male invariably proceeds to manipulate the pseudofemale beneath its abdomen to form a pair.

A 2-fold dilution series was used to investigate the bioactivity threshold of the female cue(s) as well as those of the different extracts obtained from the 'female culture water'. For these assays, samples were diluted with seawater (Table 1). Assays with extracts were undertaken 'blind', with the observer not informed about the nature and concentration of the samples, and videotaped for analysis. Negative control samples were stones and/or pre-copula males dipped into fresh new, $0.2 \mu \mathrm{m}$ sterile-filtered seawater. Male crabs were used only once a day for behavioural assays. Each arm of the Y-shaped olfactometer used for attraction assays (material: grey polyethylene) was $60 \times 20 \mathrm{~cm}$ (depth $10 \mathrm{~cm})$ with the starting tank measuring $40 \times 40 \mathrm{~cm}$. Water flow through the arms was at $2.01 \mathrm{~min}^{-1}$ providing a current of $0.1 \mathrm{~m} \mathrm{~min}^{-1}$. Substances under investigation were added to the seawater storage containers $(20 \mathrm{l})$. Arms for control/ sample were chosen at random and the olfactometer cleaned between each 10 min experiment.

Pheromone purification. Female sex pheromone(s) was collected from 2 sources: female crab-conditioned seawater (collected in the field as mating pairs) and fe-

Table 1. Carcinus maenas behavioural response upon exposure to conspecifics

\begin{tabular}{|lll|}
\hline $\begin{array}{l}\text { Exposure of } \\
\text { male to: }\end{array}$ & $\begin{array}{l}\text { Behavioural response } \\
\text { observed }\end{array}$ & $\mathrm{n}$ \\
\hline Pre-copula male & Fighting/no response & $5 / 3$ \\
Pre-copula female & Pair formation/no response & $9 / 0$ \\
Inter-moult male & Fighting/no response & $2 / 6$ \\
Inter-moult female & Pair formation/no response & $0 / 7$ \\
Control (stone) & Pair formation/no response & $0 / 10$ \\
\hline
\end{tabular}


male crab urine. Urine samples were obtained from the urinary bladder as described by Bamber \& Naylor (1996b) using a micropipette. Crab-conditioned seawater was obtained by placing a defined number of either pre-, post- or inter-moult females in freshly sterilised seawater (16 females in $800 \mathrm{ml}, 0.45 \mu \mathrm{m}$ filtered, UV irradiated) for 1 to $2 \mathrm{~h}$ followed by removal of the crabs, filtration $(0.2 \mu \mathrm{m})$ and storage at $-70^{\circ} \mathrm{C}$ until further use. To reduce the volume, samples $(200 \mathrm{ml}$ 'femaleconditioned seawater') were freeze dried and taken up in $10 \mathrm{ml}$ distilled water. Purification of active cues started with ultrafiltration $(10,1$ and $0.5 \mathrm{kDa})$ using an Amicon stirred cell ultrafiltration membrane system. Salinity of samples was determined using a refractometer (Atago) and $1 \mathrm{ml}$ of the active sample was 'desalted' using a BioRad low pressure chromatography system and a size exclusion gel column (BioRad P2, $50 \times 1.0 \mathrm{~cm}$, $1.5 \mathrm{ml} \mathrm{min}{ }^{-1}$ flow, UV detection at $254 \mathrm{~nm}$ ). Fractions were collected at 1 min intervals, bioassayed for sex pheromonal activity and then stored at $-70^{\circ} \mathrm{C}$.

Extraction and HPLC analysis. Solvent extractions were undertaken with a freshly collected sample of 'female-conditioned' seawater using n-hexane, diethylether, dichloromethane and chloroform/methanol (1/1) as solvents. Extracts were prepared using $20 \mathrm{ml}$ solvent ( 3 extraction volumes of $6.7 \mathrm{ml}$ ). The aqueous phase remaining from the first solvent extract was bioassayed for sex pheromone activity and subsequently used for extraction with the next solvent. Solid phase extractions included use of a C18 cartridge with 3 times $1 \mathrm{ml}$ ultra-pure water (fractions combined), followed by a methanol/water gradient (ranging from 0 to $100 \%$ ) in steps of $10 \%$ with $1 \mathrm{ml}$ for each step and with $1 \mathrm{ml}$ methanol/chloroform 1/1, and also using a BondElut ${ }^{\mathrm{TM}} \mathrm{SAX}$ strong anion-exchange cartridge that is ideal for the isolation of weak acids from aqueous solutions. The SAX cartridge was pre-conditioned (solvated) using $1 \mathrm{ml}$ methanol and the SAX chloride counter-ion was replaced by a less selective ion. This replacement was undertaken by rinsing the column with de-ionized water, application of $1.5 \mathrm{ml} 0.1 \mathrm{M}$ $\mathrm{KH}_{2} \mathrm{PO}_{4}$ buffer and followed by column equilibration with $0.2 \mathrm{ml}$ of a $20 \mathrm{mM}$ phosphate buffer. Sample loading was at $1 \mathrm{ml} \mathrm{min}^{-1}$ and elution was achieved using $0.5 \mathrm{M}$ phosphate buffer at $\mathrm{pH} 8$ followed by the same buffer adjusted to $\mathrm{pH} 4$ (to elute weak acids).

Initial HPLC analysis was undertaken to compare a bioactive sample from Carcinus maenas with data published by Gleeson (1984) using urine from blue crabs, Callinectes sapidus. We used a Whatman ODS 3 column $(25 \mathrm{~cm}, 10 \mu \mathrm{m}$ particle size $)$ eluting with $7 / 3$ methanol/water (isocratic) at a flow rate of $1 \mathrm{ml} \mathrm{min}{ }^{-1}$ (UV at $220 \mathrm{~nm}$ ) on a Perkin Elmer HPLC system fitted with a Waters photodiode array detector for this purpose. Since our solvent extractions implied that the pheromone is a water-soluble, highly polar molecule, this procedure is not ideal to separate the bioactive compound; however, it is essential in order to compare our data with those published by Gleeson (1984). Subsequent analyses that were undertaken to purify the shore crab pheromone(s) used either a Hypersil $^{\mathrm{TM}} \mathrm{C} 18$ or Lichrosphere ${ }^{\mathrm{TM}}$ RP18 column (both were $250 \times 4.6 \mathrm{~mm}$ ) with ultra-pure water (isocratic,

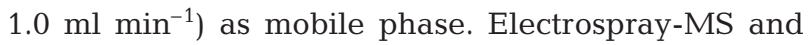
atmospheric pressure chemical ionization (APCI) was undertaken using a ThermoSeparation Navigator MS detector system connected to a Thermoquest HPLC system (P4000, AS300, chromatographic conditions as above). Synthetic 20-hydroxyecdysone (20E) was purchased as a $0.1 \mathrm{M}$ stock solution in methanol (Sigma Chemicals) and monitored by MS for masses (cone voltage $20 \mathrm{eV} \mathrm{M}^{+1}$ ) 481, 463,445, 427, 371 and $347 \mathrm{Da}$. For chemical analysis and behavioural assays, the stock solution was diluted with distilled water.

Pheromone quantification and statistical analysis of behavioural data. To achieve a rough quantification of the bioactivity, the minimum amount of a sample required to elicit a behavioural response was defined as 1 'bioassay equivalent' (BE) and the total number of BEs per sample determined. As shown in Table 2, the response of male crabs to female sex pheromone exposure varies and can be graded according to its intensity. For the bioassay equivalent determination, we used the quantity of a sample required to induce at least a Grade 4 reaction (tactile examination). This procedure enabled the relative bioactivity to be followed during the purification procedure. The proportion of males responding to phero-

Table 2. Carcinus maenas. Grading of behavioural responses of male shore crab upon exposure to female pheromone samples

\begin{tabular}{|c|c|}
\hline Grade & Response \\
\hline 1 & $\begin{array}{l}\text { No response: no behavioural change was ob- } \\
\text { served. }\end{array}$ \\
\hline 2 & $\begin{array}{l}\text { Rise to 'tip toe' posture: the random assay male } \\
\text { raises its body on extended Pereiopods } 2 \text { to } 4 \text {, } \\
\text { and may rise Pereiopod } 5 \text { above and behind the } \\
\text { posterior of the carapace. }\end{array}$ \\
\hline 3 & $\begin{array}{l}\text { Searching behaviour: the assay male engages } \\
\text { in a slow forward-searching motion towards the } \\
\text { source of the cue. }\end{array}$ \\
\hline 4 & $\begin{array}{l}\text { Tactile investigation: on locating of the 'female- } \\
\text { like object', the male engages in tactile exami- } \\
\text { nation using chelipeds to inspect the source of } \\
\text { the stimulus. }\end{array}$ \\
\hline 5 & $\begin{array}{l}\text { Adopting the pairing stance: the assay male co- } \\
\text { vers the pseudo-female, his ventral surface } \\
\text { overlying the dorsal surface of the pseudo- } \\
\text { female. The assay male uses his ptereopods to } \\
\text { clasp and support the pseudo-female from } \\
\text { below. }\end{array}$ \\
\hline
\end{tabular}


mone treatment with a clear sexual behaviour (Grade 4 or 5) is provided for all samples and analysed for statistical significance against seawater controls. Grading of responses to pheromone treatment (Table 2) also allows for statistical analysis of treatments and controls. For this, the mean response grade (and its variance) was compared between samples using Wilcoxon/Kruskal-Wallis tests and Mann-Whitney ANOVA tests with Statistica ${ }^{\mathrm{TM}}$ software.

\section{RESULTS}

\section{Development of a pheromone bioassay}

To develop a behavioural assay for pair formation that can aid the purification and identification of a female produced sex pheromone in shore crabs, animals were confronted with conspecifics. As seen in Table 1, sexual activity (approach plus formation of pairs) was observed only in 1 group, the pre-copula females plus pre-copula males. The male performed the stereotyped behaviour (see above) and proceeded to manipulate the pre-copula female beneath its abdomen to form a pair. The whole process took less than $1 \mathrm{~min}$ and the female seemed to take at least some active part in this by rising up on 'tip toe' and in some cases moving towards the male.
We placed 16 pre-moult females in $800 \mathrm{ml}$ sterile filtered seawater for $2 \mathrm{~h}$ and used this 'female-conditioned water' to stimulate 2 males in an aquarium to form a pair. The assays were undertaken 'blind' (see 'Materials and methods'). The various steps involved in the male stereotyped behaviour elicited by female-conditioned seawater can be categorised and responses to pheromonal cue(s) can be graded into 5 categories (Table 2). Scoring the degree of a response provides a statistically useful means of discriminating from inactive metabolites in biological samples.

Males responded positively when a variety of techniques were used to test female-conditioned seawater (Table 3). Dipping of a male into the female-conditioned test water and presenting it as a 'pseudofemale' to the test animal (pre-copula males) evoked pairing of the 2 males. Addition of the 'female-conditioned seawater' by pipette to 2 pre-copula males in the test aquarium also elicited pairing behaviour. Since the importance of visual cues during crab pairing has been described for many decapod species, we also conducted tests with other 'non-crab-like objects'. A pre-copula male was presented with a stone, similar in size to a female crab, that had been dipped previously into 'female-conditioned water'. Fig. 1 shows a typical response during which the pre-copula male guards the 'pseudo-female' stone, demonstrating the effective-

Table 3. Carcinus maenas. Pair formation in pre-copula males upon exposure to 'female-conditioned seawater' shore crabs

\begin{tabular}{|c|c|c|c|}
\hline Test animals (n) & Exposure to & Behavioural response & Responding crabs \\
\hline 1 male $(7)$ & 1 male & Fighting & $7 / 7$ \\
\hline 1 male (5) & Pre-moult female & Pair formation & $5 / 5$ \\
\hline 1 male (10) & 'Female-conditioned seawater' & $\begin{array}{l}\text { a) Rising on tip toe } \\
\text { b) Searching }\end{array}$ & $\begin{array}{l}\text { a) } 10 / 10 \\
\text { b) } 9 / 10\end{array}$ \\
\hline 1 males $(6)^{a}$ & $\begin{array}{l}\text { 'Female-conditioned seawater' } \\
(1 \mathrm{ml})\end{array}$ & $\begin{array}{l}\text { a) Tip toe/searching } \\
\text { b) Pair formation }\end{array}$ & $\begin{array}{l}\text { a) } 2 / 2 \text { (6 replicates) } \\
\text { b) } 6 / 6\end{array}$ \\
\hline 2 males $(6)^{\mathrm{a}}$ & $\begin{array}{l}\text { 'Female-conditioned seawater' } \\
(0.1 \mathrm{ml})\end{array}$ & $\begin{array}{l}\text { a) Tip toe/searching } \\
\text { b) Pair formation }\end{array}$ & $\begin{array}{l}\text { a) } 2 / 2 \text { (6 replicates) } \\
\text { b) } 0 / 6\end{array}$ \\
\hline 1 male $(10)$ & $\begin{array}{l}\text { Male (dipped into 'female- } \\
\text { conditioned seawater') }\end{array}$ & $\begin{array}{l}\text { a) Tip toe/searching } \\
\text { b) Pair formation }\end{array}$ & $\begin{array}{l}\text { a) } 2 / 2 \text { (10 replicates) } \\
\text { b) } 7 / 10\end{array}$ \\
\hline 1 male (5) & $\begin{array}{l}\text { Half a tennis ball dipped into } \\
\text { 'female-conditioned seawater' }\end{array}$ & $\begin{array}{l}\text { a) Tip toe/searching } \\
\text { b) Pair formation }\end{array}$ & $\begin{array}{l}\text { a) } 5 / 5 \\
\text { b) } 4 / 5\end{array}$ \\
\hline 1 male (10) & $\begin{array}{l}\text { Stone dipped into 'female- } \\
\text { conditioned seawater' }\end{array}$ & $\begin{array}{l}\text { a) Tip toe/searching } \\
\text { b) Pair formation }\end{array}$ & $\begin{array}{l}\text { a) } 10 / 10 \\
\text { b) } 8 / 10\end{array}$ \\
\hline 2 males $(8)^{b}$ & $\begin{array}{l}\text { Stone dipped into: 'female- } \\
\text { conditioned seawater' }\end{array}$ & $\begin{array}{l}\text { a) Short duration fighting } \\
\text { b) Pair formation (stone) } \\
\text { c) Pair formation (males) }\end{array}$ & $\begin{array}{l}\text { a) } 6 / 8 \\
\text { b) } 6 / 8 \\
\text { c) } 2 / 8\end{array}$ \\
\hline 1 male (4) & $\begin{array}{l}\text { Inter-moult female dipped in } \\
\text { 'female-conditioned seawater' }\end{array}$ & $\begin{array}{l}\text { a) Tip toe/searching } \\
\text { b) Pair formation }\end{array}$ & $\begin{array}{l}\text { a) } 4 / 4 \\
\text { b) } 3 / 4\end{array}$ \\
\hline 5 males, $(6)^{\mathrm{a}}$ & $\begin{array}{l}\text { 'Female-conditioned seawater' } \\
(2 \mathrm{ml})\end{array}$ & $\begin{array}{l}\text { a) Tip toe/searching } \\
\text { b) Pair formation }\end{array}$ & $\begin{array}{l}\text { a) } 27 / 30 \\
\text { b) } 5 / 5\end{array}$ \\
\hline 1 female (16) & 'male-conditioned seawater' & Rising on tip toe & $11 / 16$ \\
\hline
\end{tabular}




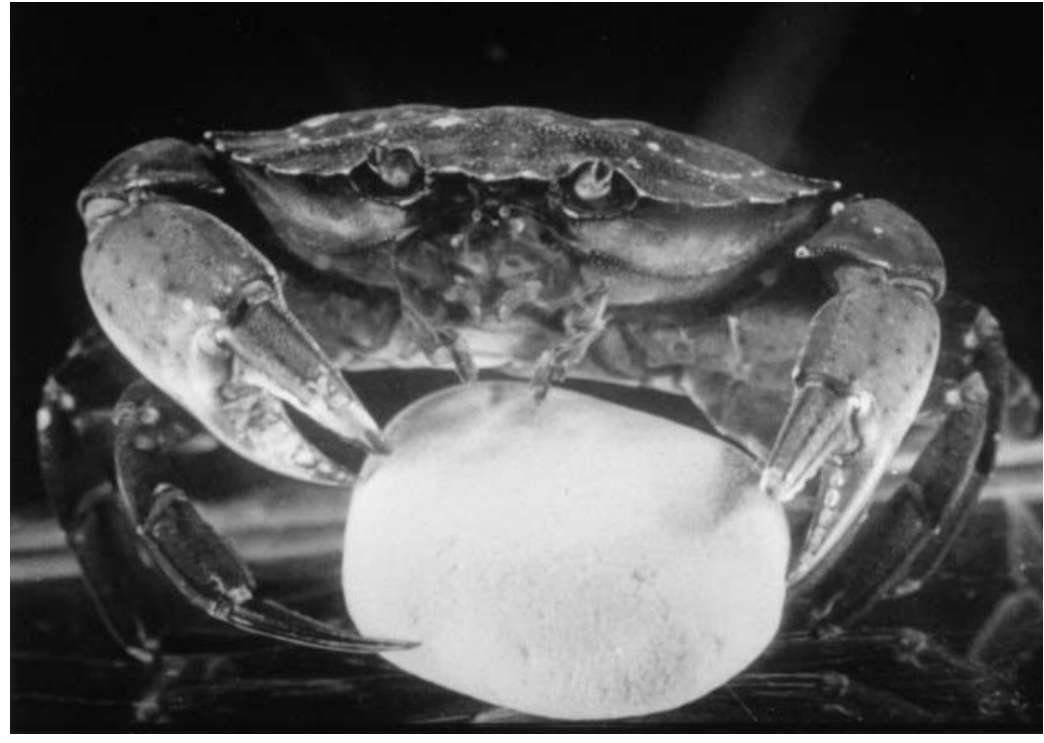

Fig. 1. Carcinus maenas sex pheromones. Response of a randomly selected male to a 'female-conditioned seawater-dipped' stone

ness of the female pheromone as the dominant factor causing pairing in shore crabs.

Fig. 2 shows the graded response of randomly selected assay males to female-conditioned seawater-dipped pebbles and to application of the sample on to the carapace of a 'pseudo-female'. Both application procedures give significantly (Mann-Whitney ANOVA, $\mathrm{p}<0.001$ ) greater responses than the seawater controls.

When 2 pre-copula males in the assay tank were confronted with a 'female-conditioned seawater' prepared stone, they showed short intense fighting followed by pairing of the dominant male with the stone (Table 3). In 2 cases, the dominant male in the experiment ignored the stone and paired with the other precopula male (Table 3). The addition of $2 \mathrm{ml}$ femaleconditioned seawater to a group of males $(n=5,50 \mathrm{l}$ tank) resulted in a chaotic melee, during which all males attempted to form pairs with each other. All the observed reactions to pseudo-females occurred within 1 min of exposure and in many cases within a few seconds.

Pairing of shore crabs requires that the sexual partners first meet and many efforts have been made (see Bamber \& Naylor 1996a for a review) to identify possible femaleproduced sex attractants. We therefore also investigated whether the chemical signal(s) responsible for the formation of the pair also attracts pre-copula males. Using a dilution series of 'female-conditioned' seawater, we determined that exposure of males to smaller quantities of the female pheromone $(<0.1 \mathrm{ml})$ failed to elicit the complete pairing behaviour. Instead, the pre-copula males were induced to rise up and start the typical searching behaviour (Grade 3 response), but pairing did not occur. Further dilution of the cue (addition of $0.01 \mathrm{ml}$ ) evoked only the elevated posture and some degree of searching behaviour (Table 3; Grades 2 and 3 response). A Y-shaped olfactometer was used to test the potential 'attractiveness' of the female-conditioned water $(5 \mathrm{ml}$ in $500 \mathrm{ml}$ seawater, $10 \mathrm{ml} \mathrm{min}{ }^{-1}$ flow). Significantly more (n = 56 males, Mann-Whitney; Chisquare: $18.25, \mathrm{df}=1, \mathrm{p}<0.001$ ) males preferred the 'female-conditioned seawater' arm to the seawater control arm $(\mathrm{n}=10$ males) and 4 males did remain in the starting area of the olfactometer. In contrast, only $32.8 \%(\mathrm{n}=23)$ of the crabs moved towards the pheromonetreated arm when confronted with mussel flesh (Mytilus edulis) odour in the control arm. Of the males, $61.4 \%(n=43)$ moved towards the mussel flesh and $5.8 \%(n=4)$ stayed in the olfactometer starting-tank, providing no significant difference between the 2 treatment groups (Mann-Whitney; Chisquare: $3.10, \mathrm{df}=1, \mathrm{p}=0.078$ ).

Observations made during the course of this investigation suggested that females do not play an entirely passive role in mating. A preliminary investigation of whether 'male-conditioned seawater' elicits a charac-

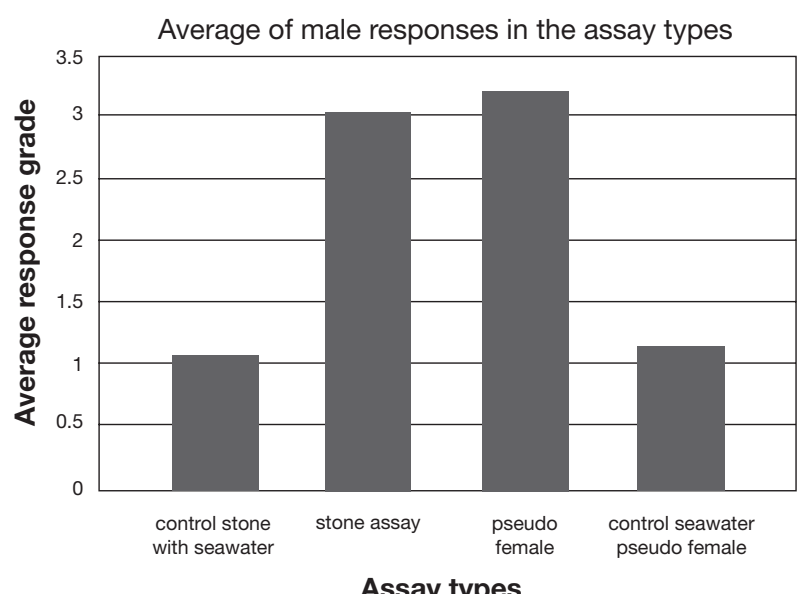

Fig. 2. Carcinus maenas sex pheromones. Behavioural response of randomly selected assay males to 'female-conditioned seawater dipped' stones and to pipetting of the sample on to the carapace of a male (the 'pseudo-female'). Data provided are average responses ( $\mathrm{n}=43$ males). Statistically significant response (Mann-Whitney ANOVA, $\mathrm{p}<0.001$ ). Grading of response: (1) no behavioural change observed; (2) rise to 'tip toe' posture; (3) searching behaviour; (4) tactile investigation (using chelipds) of the source of the stimulus; and (5) adopting the pairing stance 
teristic response in females showed that 11/16 females which were exposed to $1 \mathrm{ml}$ of 'male-conditioned seawater' in a $600 \mathrm{ml}$ test tank (5 males in $2.5 \mathrm{l}$ for $2 \mathrm{~h}$ ) showed instant signs of detection of a chemical cue (Table 3). These reactions included an increased rate of flicking of the antennules and subsequent elevation on 'tip toe', similar to the behaviour observed in male shore crabs. Re-use of animals for behavioural assays is seen as problematic because of possible effects of priming and learning. Shore crabs that were used for bioassays were therefore only used every 2 to $3 \mathrm{~d}$ and kept in communal tanks.

\section{Purification of the female produced pheromone}

'Female-conditioned seawater' from 16 shore crabs (in $800 \mathrm{ml}$ seawater) induced pair formation in 8/8 males with a minimum exposure dose of $0.1 \mathrm{ml}$. Subsamples of $200 \mathrm{ml}$ (equalling 2000 bioassay equivalents, termed Sample A) were used for solvent extractions and solid phase extraction, in order to obtain information on the chemical nature/solubility of the sex pheromone. No bioactivity was recorded in nhexane, diethylether, dichloromethane or chloroform/methanol (1/1) extractions, and Table 4 shows that the cue was not or only weakly retained on a $\mathrm{C}_{18}$ solid phase extraction cartridge or on a SAX anion exchange column (Kruskal-Wallis ANOVA, no difference compared to female-conditioned seawater: chi square: 1.604 , df $=3, \mathrm{p}=0.901$ ).

In the bioassay, both urine and 'female-conditioned seawater' were biologically active and filtration through a 10 and $1 \mathrm{kDa}$ filter did not reduce their activity

Table 4. Carcinus maenas. Behavioural assays with males exposed to extracts obtained from 'female-conditioned seawater' $(200 \mathrm{ml})$ termed 'Sample A'. Tests made use of 'the dipped stone' assay

\begin{tabular}{|c|c|c|c|}
\hline Samples under investigation & $\begin{array}{l}\text { Responding } \\
\text { crabs } \\
\text { (n) }\end{array}$ & $\begin{array}{l}\text { Mean of } \\
\text { response } \\
\text { grade }^{\mathrm{a}}\end{array}$ & $\begin{array}{c}\text { Bioassay } \\
\text { equivalents } \\
(B E)^{b}\end{array}$ \\
\hline 'Female-conditioned seawater' & $22 / 24$ & 4.13 & 2000 in $0.1 \mathrm{ml}$ \\
\hline (A) - after $\mathrm{C}_{18}$ cartridge & $16 / 16$ & 4.06 & 1950 \\
\hline (A) - after SAX cartridge & $15 / 16$ & 4.00 & 1900 \\
\hline 10 kDa filtrate of $(\mathrm{A})$ & $14 / 15$ & 3.87 & 2000 \\
\hline $1 \mathrm{kDa}$ filtrate & $14 / 15$ & 4.07 & 1850 \\
\hline 500 Da filtrate & $6 / 15$ & 2.35 & 250 \\
\hline Supernatant of $500 \mathrm{Da}$ filtration & $13 / 15$ & 4.07 & 1600 \\
\hline 20-Hydroxyecdysone $\left(0.1 \mu \mathrm{g} \mathrm{ml}^{-1}\right)$ & $1 / 15$ & 1.28 & - \\
\hline 20-Hydroxyecdysone $\left(1 \mu \mathrm{g} \mathrm{ml}^{-1}\right)$ & $1 / 15$ & 1.42 & - \\
\hline 20-Hydroxyecdysone $\left(10 \mu \mathrm{g} \mathrm{ml}^{-1}\right)$ & $1 / 16$ & 1.21 & - \\
\hline Inter-moult female & $2 / 15$ & 1.86 & - \\
\hline
\end{tabular}

significantly (Kruskal-Wallis ANOVA, no difference compared to female-conditioned seawater and solid phase extraction cartridges: Chi-square: 1.621, df = 5, $\mathrm{p}=0.914)$. In contrast, the 500 Da filter eluate was significantly less active (250 BE, Kruskal-Wallis ANOVA, different compared to 'female-conditioned seawater', $10 \mathrm{kDa}, 1 \mathrm{kDa}$ filtration and SPE cartridge extractions: Chi-square: 43.270 , df $=7, \mathrm{p}<0.001$ ), the majority of the pheromone remained in the supernatant of the 500 Da filter (1600 BE, Table 4, Kruskal-Wallis ANOVA, no difference compared to 'female-conditioned seawater' and SPE cartridge extractions: Chi-square: $1.604, \mathrm{df}=5, \mathrm{p}=0.90$ ). The supernatant of the $500 \mathrm{Da}$ filtration was, as in the next purification step, passed through a low-pressure liquid chromatography column packed with a molecular weight separation gel (BioRad P2), in order to separate the active cue from inorganic salts that may have remained on the filter. Salts, such as $\mathrm{NaCl}$ and $\mathrm{KCl}$, should pass through $500 \mathrm{Da}$ membranes. Nevertheless, a well-known problem in ultra-filtration as well as dialysis membranes is that compounds 'fall out of solution' when the solvent (water) passes through. This is because the compound's concentration in the supernatant will become higher than its solubility. Fractionation of the extract after BioRad P2 separation yielded only 1 active fraction eluting separately from the salt front by 2 min and characterised by a UV absorbance maximum at $202.9 \mathrm{~nm}$ (Fig. 3). The HPLC analysis of this biologically active desalted sample is shown in Fig. 3. HPLC analysis also demonstrated that similar to Callinectes sapidus (Gleeson et al. 1984), female Carcinus maenas release only a limited number of compounds, one of them having a similar retention index to 20-hydroxyecdysone (Fig. 3).

Electrospray-MS coupled with HPLC analysis showed that the peak at $5.6 \mathrm{~min}$ is 20-hydroxyecdysone. The insert in Fig. 3A, however, shows that the use of electrospray as the application technique for mass spectrometry of the pheromone failed to produce a spectrum of the bioactive compound(s). Although a UV signal of higher intensity to the 20-hydroxyecdysone standard (100 ng synthetic 20 hydroxyecdysone added, retention time is $5.65 \mathrm{~min}$ ) exists, the total ion count (TIC) at the pheromone fraction (retention time 2.35 to $3.4 \mathrm{~min}$ ) is negligible. This indicates that the pheromone is unlikely to be similar to 20-hydroxyecdysone. Synthetic 20-hydroxyecdysone also failed to induce sexual behaviour in the bioassays (Table 4; Kruskal- Wallis Test compared to seawater control: Chisquare: 1.069 , df $=3, \mathrm{p}=0.586$ ). 


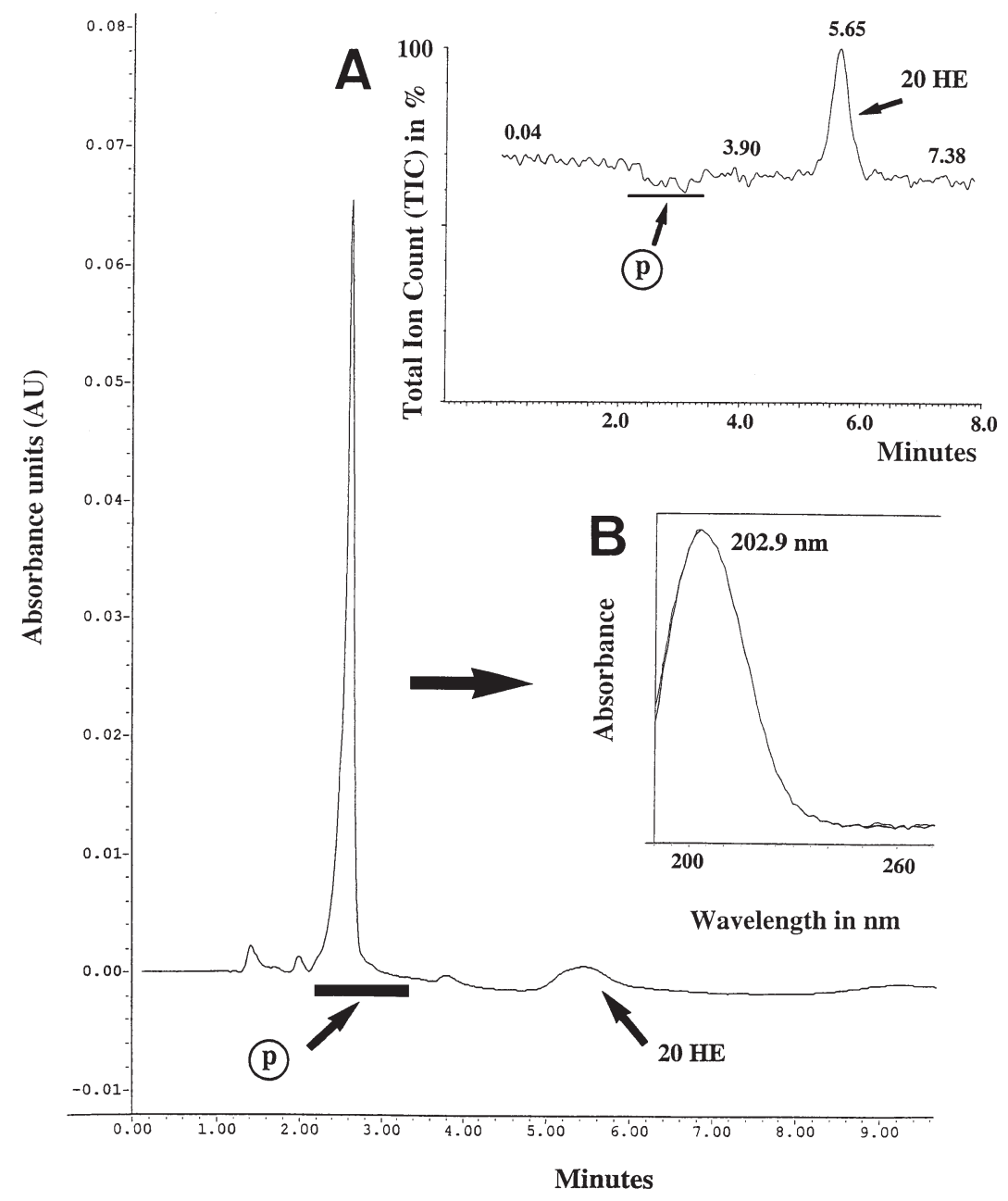

Fig. 3. Chromatogram of a 500 Da filtrate of 'female-conditioned seawater' collected from Carcinus maenas (Electrospray Mass spectrometry (ES+, cone voltage $30 \mathrm{eV}$ ) coupled to HPLC; conditions: Lichrosphere ${ }^{\mathrm{TM}} \mathrm{RP} 18,250 \times 4.6 \mathrm{~mm}$ column with ultra-pure water isocratic, $1.0 \mathrm{ml} \mathrm{min}^{-1}$ as mobile phase, detection via $\mathrm{UV}$ at $210 \mathrm{~nm} ; \mathrm{P}=$ bioactive pheromone fraction, $20 \mathrm{HE}=20$-Hydroxyecdysone), using a Thermo-Separation ${ }^{\mathrm{TM}}$ Navigator MS detector system connected to a Thermoquest HPLC system (P4000, AS300). (A) Total ion count (TIC) of chromatogram shown in (B). UV spectrum analysis of largest peak in the bioactive fraction of the sample, $\mathrm{P}=$ bioactive pheromone fraction, $20 \mathrm{HE}=$ 20 -Hydroxyecdysone; $100 \mathrm{ng}$ of synthetic $20 \mathrm{HE}$ were added to the sample as internal standard

\section{DISCUSSION}

Despite considerable efforts, no crustacean sex pheromone has yet been fully characterised (Dunham 1988). Although Carcinus maenas has frequently been the subject of investigation (see Bamber \& Naylor 1996a for a review), no structural information on the female sex pheromone is available. The present paper confirms the existence of a female sex pheromone and establishes a simple, unambiguous behavioural bioassay for it. As described for Gammarus duebenii
(Hartnoll \& Smith 1980), formation of pairs prior to reproduction in Carcinus maenas is limited to heterosexual partners, whereas male-male interactions of sexually active individuals usually induce fighting behaviour (Sneddon et al. 1997, 2000a,b). In the shore crab, the factor that enables a male crab to detect the opposite sex is predominantly the subject's odour (Table 1). As described by Berrill \& Arsenault (1982), both sexes detect a chemical cue in 'conditioned seawater' that elicits a stereotyped sexual behaviour. Our behavioural observations of separated pre-copula pairs have confirmed in Carcinus maenas the observations of Gleeson (1991) on Callinectes sapidus that females do not exhibit a simply passive role in courtship behaviour. Significantly, we have also demonstrated that 'male-conditioned seawater' elicits a characteristic response in females. This reaction is similar to the elevated stance of males when exposed to 'female-conditioned seawater'. The source of the 'water-borne' female pheromone in decapod Crustacea is still not clear, but urine sampled from the nephropore rosette glands has been suggested by Bushmann \& Atema (1996) in the lobster Homarus americanus. In Carcinus maenas, Bamber \& Naylor (1996b) obtained evidence of an additional source of the female sex pheromone and suggested that diffusion across the gills may occur.

Our experiments demonstrate that the role of visual and tactile cues in shore crab reproduction, which have driven the development of attraction chambers to limit visual cues (see Dunham 1978 for a review), has been overestimated. Following the detection of the natural pheromone signal, all aspects of the pairing behaviour of male crabs will be elicited and even noncrab-like objects, such as a stone, will be dealt with as if they were a female crab (Table 3, Fig. 1). Pair formation, a typical 'releaser reaction', with a stereotyped sexual behaviour is now seen as more relevant and discriminating than 'attraction chamber' assays (Kamio et al. 2000). Provided with the choice between feeding stimulants and sex pheromone attractants, the majority of shore crabs chose food in our study. Dunham (1978), in a critical review on the failure of sex pheromone 
research in crustaceans, highlighted problems with the attraction chamber assay employed by Kittredge et al. (1971) and others (Eales 1974, Seifert 1982). In fact, most of the controversy in the literature regarding crustacean sex pheromones can be traced to the bioassay. A key factor is the need to employ males that are receptive to female pheromones (Bamber \& Naylor 1996a) and subsequently, to develop an assay, which allows differentiation of sexual behaviour (attraction, courtship display) and other environmental signals, such as food attractants (Dunham 1988). Consequently, movement towards the attractant source in a chemotactic response (e.g. in a Y-shaped olfactometer as frequently used for insects, or an actograph design, see Bamber \& Naylor 1996b) is not capable of discriminating between locomotion activity and sexual attraction.

As highlighted by Dunham (1988), an assay developed for sex pheromone research has to be able to discriminate between non-active cues to allow purification and chemical identification. This requires both negative and positive controls as included in the present assay. In our approach, male crabs (or a stone), prior to treatment with 'female-conditioned seawater', are not attractive and/or inductive and any positive response in the ensuing assay has to be based on the 'treatment' of the test object with a substance under investigation (see Tables $2 \& 3$ ). Positive controls are the females that produced the chemical signal. In contrast to bioassays based solely on the attraction towards the opposite sex, the new 'homosexual pair formation' assay is capable of discriminating between conflicting signals, such as food and visual cues. The assay technique is potentially transferable to a number of crustacean species, such as the blue crab Callinectes sapidus or gammarid amphipods (Hartnoll \& Smith 1979, 1980). Similar assays were used successfully in the study of insect sex pheromones, e.g. in tsetse flies (Langley et al. 1975).

There are numerous examples of reliable bioassays for pheromone research in insects (Shorey 1977). The recent identification of sex pheromones in nereidid polychaetes and the extraordinary, complete picture of pheromone communication in brown algae reproduction were made possible by the development of fast and reliable behavioural assays (see Hardege 1999 for a review). In the nereidid polychaetes, such assays were complemented by electrophysiological measurements of receptor stimulation (Zeeck et al. 1988, Ram et al. 1999) and future investigations with shore crabs will also focus on the location of the pheromone receptor. The male antennules have been described as bearing the receptors for female sex pheromones in a number of crustaceans including the blue crab Callinectes sapidus (Gleeson 1980) and also in Carcinus maenas (Bamber \& Naylor 1996a). In the lobster Homarus americanus, Atema (1995) and Gomez \& Atema (1996) were able to demonstrate that during detection of feeding stimulants, olfactory receptor cells located on the lateral antennules encode the signals using a specific frequency of olfactory sampling.

Re-use of animals for behavioural assays is seen as problematic because of possible effects of priming and learning. Crabs that were used for bioassays were therefore released into a communal tank once assays were finished and were not re-used for at least $2 \mathrm{~d}$. Assays were also undertaken 'blind', with the observer not informed about the nature and concentration of the samples, and videotaped for analysis. No increase of sensitivity of males over time was detected, and levels of responses to negative and positive controls remained consistent throughout the experiments. This suggests that in contrast to American lobster dominance fights (Karavanich \& Atema 1998, Breithaupt \& Atema 2000), shore crabs do not recognise individuals or 'remember' chemical signals. 'Learning' of the sex pheromone 'odour' provided with, e.g. the stone, and subsequent recognition that the pheromone-treated object is not a freshly moulted female would have also rather decreased, not increased, the response of males, because no 'reward' will be associated with the stone. Future advancements of the bioassay procedure should include regular use of positive controlsmeaning that crabs tested negative will in future studies always be confronted with freshly moulted females to test whether the sample added was inactive rather than the male not responsive.

The cuticular glycoprotein arthropodin that mediates barnacle settlement of cypris larvae, has been postulated as a potential crustacean sex pheromone (Dunham 1988). Our results show that in Carcinus maenas, arthropodin (molecular size in barnacles is $>200 \mathrm{kDa}$ ) is not the female sex pheromone (Table 4 ) because the bioactive compound is less than $1000 \mathrm{Da}$. At this stage, we cannot rule out that a small derivative or breakdown product (peptide) of arthropodin (as defined by Clare \& Matsumura 2000) functions as the sex pheromone, and that arthropodin and/or related cuticular proteins might be involved in contact chemoreception. Size exclusion chromatography using a Shodex OHpak (SB-802-HQ) column and a polyethylene glycol (PEG) standard mixture (MW 940, 580, 400 Phenomenex, data not shown) show the largest peak in the size exclusion chromatography of the bioactive fraction to have a size of ca 480 to $520 \mathrm{Da}$ (compared to PEG). Since we cannot be absolutely sure that the large peak within the bioactive fraction is the pheromone or whether a minor peak or even a compound that is 'hidden' under the peak is the pheromone, it remains unclear if ca. 500 Da represents the size of the pheromone. 
The existence of female sex pheromones has been predicted in almost all those crustacean species where female ecdysis and mating are linked (Christoffersen 1978). This is especially the case where copulation is possible only during a short period after the moult before a physical barrier develops to male first pleopod insertion (Nelson 1991). It is therefore to be expected that elaborate methods to signal a potential mate have evolved. Early reports indicated that 20-hydroxyecdysone, the crustacean moulting hormone, is the sex pheromone of several crab species (Kittredge et al. 1971). Many authors, including Gleeson et al. (1984), have since provided convincing evidence that, for a number of crab species, such as Callinectes sapidus, this is not the case. 20-hydroxyecdysone is present in the 'conditioned seawater' sample (Fig. 3), but not detectable in the biologically active fraction (Fig. 3) obtained from female Carcinus maenas. Synthetic 20-hydroxyecdysone also failed to induce sexual behaviour in males (Table 4). Although this study does not completely negate a steroidal character for the sex pheromone, the LC-MS analyses utilising electrospray and APCI did not indicate the presence of any steroid in the bioactive fraction (Fig. 3A). The HPLC analysis of the Carcinus maenas pheromone using an ODSIII column with a methanol gradient (method used by Gleeson et al. 1984) shows a similar retention index (3.4 to $4.0 \mathrm{~min}$, chromatogram not shown) to that detected by Gleeson et al. (1984) in the blue crab Callinectes sapidus. Recent investigations into species specificity in polychaete sex pheromones revealed a degree of heterospecificity in nereidid sex pheromones (see Hardege et al. 1998 for a review). Coelomic fluid collected from ripe worms contained sex pheromones of a number of closely related species (Hardege 1999). Future studies with Carcinus maenas will also focus on species specificity and evaluate the opportunity to utilise samples and/or bioassays from related species, such as the blue crab, to identify the Carcinus female sex pheromone.

The purification and identification of the female sex pheromone from 'female-conditioned seawater' rather than from body fluids reduces the number of compounds in the sample (see Fig. 3). At the same time, it represents an analytical challenge because of the dilution of the pheromone and the presence of inorganic salts. A purification strategy similar to those used successfully in ragworms (Müller et al. 1999) has been utilised in the present study. Because of the insolubility of the pheromone in organic solvents (Table 3), the approach uses molecular size filtration, desalting, size exclusion chromatography and HPLC fractionation. Current data suggest that the pheromone is a small (under $1000 \mathrm{Da}$ ), polar molecule lacking a UV-active chromophore (UV absorbance max at $202.9 \mathrm{~nm}$, Fig. 3B). The cue is water-soluble, but we have not detected an interpretable spectrum via electrospray and
APCI mass spectrometry (Fig. 3A). This could either be because of insufficient quantity of purified material or the failure of these 2 methods to ionise the molecule for mass spectrometry. The existence of a peak (UV max at 202.9 nm; Fig. 3) within the bioactive fraction and the measurable refractive index of the purified, saltfree sample suggest the existence of measurable quantities of organic material in the sample. Although there are chemicals, such as carbohydrates, that would fit this chemical description and although our data limit the range of possible compounds that may function as the sex pheromone, to date we have no clear indication of its possible structure. Studies in the forthcoming reproductive seasons will focus on accumulating sufficient amounts of purified pheromone to undertake further analysis, e.g. via NMR.

The 'homosexual approach bioassay' developed for shore crabs in the current investigation, should be applicable to the sex pheromone of other Brachyura ${ }^{1}$. The present investigation has already enabled us, at least for the shore crab, to discount 2 existing sex pheromone hypotheses. Both molecules suggested previously, 20hydroxyecdysone and arthropodin, are not detectable in the bioactive fractions of samples collected from female shore crabs (Fig. 3). We have confirmed the existence of a female-produced sex pheromone in shore crabs and established a practical strategy for its characterisation as well as providing a number of physico-chemical characteristics of the active cue.

Acknowledgements. The authors would like to thank Dr. S. Bamber, R. Anning, Dr. M. Beckmann and Dr. H. BartelsHardege for their help during collection of crabs and for fruitful discussions. We are grateful to Prof. D. W. Knight from the department of Chemistry at Cardiff University for the use of Electrospray-MS facilities, Dr. T. Breithaupt for advise on statistical analysis and S. Harrison for conducting the LC-MS analyses. This work was supported by a Peter Baker Fellowship of the Marine Biological Association, and grants from The Wellcome Trust and National Environmental Research Council, UK, to J.D.H. and by a Leverhulme Trust grant to J.D.H., M.G.B. and A.S.C.

\section{LITERATURE CITED}

Atema J (1995) Chemical signals in the marine environment: dispersal, detection, and temporal signal analysis. Proc Natl Acad Sci USA 92:62-66

Bamber SD, Naylor E (1996a) Chemical communication and behavioural interaction between sexually mature male and female shore crabs (Carcinus maenas). J Mar Biol Assoc UK 76:691-699

Bamber SD, Naylor E (1996b) Sites of release of putative sex pheromone and sexual behaviour in the female common shore crab Carcinus maenas. Estuar Coast Shelf Sci 44: 195-202

${ }^{1} \mathrm{~A}$ similar assay was used by Kamio et al. (2002) 
Bamber SD, Naylor E (1996c) The mating behaviour of male Carcinus maenas in relation to a putative sex pheromone: behavioral changes in response to antennule restriction. Mar Biol 125:483-488

Berrill M, Arsenault M (1982) Mating behaviour of the green shore crab, Carcinus maenas. Bull Mar Sci 32:632-638

Bouchard S, Sainte-Marie B, McNeil JN (1996) Indirect evidence indicates female semiochemicals release male precopulatory behaviour in the snow crab, Chinoecetes opilio (Brachyura: Majidae). Chemoecology 7:39-44

Breithaupt T, Atema J, (2000) The timing of chemical signaling with urine in dominance fights of male lobsters (Homarus americanus). Behav Ecol Sociobiol 49:67-78

Bushmann PJ, Atema J (1996) Nephropore rosette glands of the lobster Homarus americanus-possible sources of urine pheromones. J Crustac Biol 116:221-231

Christofferson JP (1978) Evidence for the controlled release of a crustacean sex pheromone. J Chem Ecol 4:633-639

Clare AS (1995) Chemicals signals in barnacles: old problems, new approaches. In: Schram FR, Høeg JT (eds) New frontiers in barnacle evolution. AA Balkema, Rotterdam, p 49-67

Clare AS, Matsumura K, (2000) Nature and perception of barnacle settlement pheromones. Biofouling 15:57-71

Cohen AN, Carlton JT, Fountain MC (1995) Introduction, dispersal and potential impacts of the green crab Carcinus maenas in San Francisco Bay, California. Mar Biol 122: 225-237

Cowan D, Atema J (1990) Moult staggering and serial monogamy in American lobsters, Homarus americanus. Anim Behav 39:1199-1206

Dunham PJ (1978) Sex pheromones in Crustacea. Biol Rev 53:555-583

Dunham PJ (1988) Pheromones and behaviour in Crustacea. In: Laufer H, Downer R (eds) Endocrinology of selected invertebrate types. Alan R Liss, New York, p 375-392

Eales AJ (1974) Sex pheromone in the shore crab Carcinus maenas, and the site of its release from females. Mar Behav Physiol 2:345-355

Gleeson RA (1980) Pheromone communication in the reproductive behaviour of the blue crab, Callinectes sapidus. Mar Behav Physiol 7:119-134

Gleeson RA (1982) Morphological and behavioural identification of the sensory structures mediating pheromone reception in the blue crab, Callinectes sapidus. Biol Bull 163:162-171

Gleeson RA (1991) Intrinsic factors mediating pheromone communication in the blue crab, Callinectes sapidus. In: Bauer RT, Martin JW (eds) Crustacean sexual biology. Columbia University Press, New York, p 17-32

Gleeson RA, Adams MA, Smith AB (1984) Characterisation of a sex pheromone in the blue crab Callinectes sapidus. J Chem Ecol 10:913-921

Gomez G, Atema J (1996) Temporal resolution in olfaction: stimulus integration time of lobster chemoreceptor cells. J Exp Biol 199:1771-1779

Hardege JD (1999) Nereidid polychaetes as model organism for marine chemical ecology: a review. Hydrobiologia 402: $145-161$

Hardege JD, Bartels-Hardege HD, Wu BL, Zhu MY, Yang Y, Zeeck E (1994) Environmental control of reproduction of Perinereis nuntia var brevicirrus Grube, 1857. J Mar Biol Assoc UK 74:903-918

Hardege JD, Bentley MG, Beckmann M, Müller C (1996) Sex pheromones in marine polychaetes: volatile organic substances (VOS) isolated from Arenicola marina. Mar Ecol Prog Ser 139:157-166

Editorial responsibility: Otto Kinne (Editor), Oldendorf/Luhe, Germany
Hardege JD, Müller CT, Beckmann M, Bartels-Hardege HD, Bentley MG (1998) Timing of reproduction in marine polychaetes: the role of sex pheromones. Ecoscience 5:395-404

Hartnoll RG (1969) Mating in the Brachyura. Crustaceana 16: 161-181

Hartnoll RG, Smith SM (1979) Pair formation in the edible crab, Cancer pagurus, Decapoda, Brachyura. Crustaceana 36:23-28

Hartnoll RG, Smith SM (1980) An experimental study of the sex discrimination and pair formation in Gammarus duebenii. Crustaceana 38:253-264

Kamio M, Matsunaga S, Fusetani N (2000) Studies on sex pheromones of the helmet crab, Telmessus cheiragonus. 1. An assay based on precopulatory mate-guarding. Zool Sci 17:731-733

Kamio M, Matsunaga S, Fusetani N (2002) Copulation pheromone in the crab Telmessus cheiragonus (Brachyura: Decapoda). Mar Ecol Prog Ser 234:183-190

Karavanich C, Atema J (1998) Individual recognition and memory in lobster dominance. Anim Behav 56:1553-1560

Kittredge JS, Terry M, Takahashi FT (1971) Sex pheromone activity of the moulting hormone crustecdysone on male crabs (Pachygrapsus crassipes, Cancer antennarius and Cancer anthonyi). Fish Bull 69:337-343

Langley PA, Pimley RW, Carlson DA (1975) Sex recognition pheromone in tsetse fly Glossina morsitans. Nature 254: $51-53$

Müller CT, Beckmann M, Hardege JD (1999) Sex pheromones in Nereis succinea. J Invertebr Reprod 36(1):183-186

Nelson K (1991) Scheduling of reproduction in relation to molting and growth in malacostracan crustaceans. In: Wenner A, Kuris A (eds) Crustacean egg production. AA Balkema, Rotterdam, p 77-113

Ram JL, Müller CT, Beckmann M, Hardege JD (1999) The spawning pheromone cysteine-glutathione disulfide ('Nereithione') arouses a multicomponent nuptial behaviour and electrophysiological activity in Nereis succinea males. FASEB J 13:945-952

Ryan EP (1966) Pheromone: evidence in decapod Crustacea. Science 151:340-341

Seifert P (1982) Studies on the sex pheromone of the shore crab, Carcinus maenas, with special regard to ecdysone excretion. Ophelia 21:147-158

Shorey HH (1977) Animal communication by pheromones. Academic Press, New York

Sneddon LU, Huntingford FA, Taylor AC (1997) Weapon size versus body size as a predictor of winning in fights between shore crabs, Carcinus maenas. Behav Ecol Sociobiol 41:237-242

Sneddon LU, Huntingford FA, Taylor AC, Orr FC (2000a) Weapon strength and competitive success in the fights of shore crabs (Carcinus maenas). J Zool 250:397-403

Sneddon LU, Taylor AC, Huntingford FA, Watson DG (2000b) Agonistic behaviour and biogenic amines in shore crabs Carcinus maenas. J Exp Biol 203:537-545

Zeeck E, Hardege JD, Bartels-Hardege HD, Wesselmann G (1988) Sex pheromone in a marine polychaete: determination of the chemical structure. J Exp Zool 246:285-292

Zeeck E, Hardege JD, Bartels-Hardege HD (1990) Sex pheromones and reproductive isolation in two nereid species, Nereis succinea and Platynereis dumerilii. Mar Ecol Prog Ser 67:183-188

Zeeck E, Harder T, Beckmann M, Müller CT (1996) Marine gamete-release pheromones. Nature 382:214

Zeeck E, Harder T, Beckmann M (1998) Uric acid — the sperm release pheromone of the marine polychaete Platynereis dumerilii. J Chem Ecol 24:13-23

Submitted: August 16, 2000; Accepted: August 26, 2002

Proofs received from author(s): November 12, 2002 